\title{
The Thucydides Tapes
}

\author{
Peter Singer, Harvard University
}

$R$ anking with the Rosetta Stone and Dead Sea Scrolls, the recently discovered transcripts of the Hellenic Political Science Association Conferences represent a scholarly find that opens up new avenues of understanding into the ancient past. Hidden for over two thousand years, the existence of the transcripts was unknown until just last year, when they were literally stumbled over by a young American graduate student during a spring-break hiking trip in Greece. The tapes cover the academic conferences that took place at the height of the Peloponnesian War, the war between the alliances of Athens and Sparta lasting 431 to $404 \mathrm{BCE}$. This monumental conflict has since served as a teaching tool for all measures of political theory and the classical metaphor for everything from the start of the Cold War to the decline of American society and power. At last, in what many are now calling the "Thucydides Tapes," the reader truly has what many scholars have long dreamed of: a "fly on the wall" perspective on a major event of ancient history.

Pete Singer is a graduate student in the department of government at Harvard University. This paper was written for his field seminar in response to the question: "How do the modern theories of international relations account for the origins of the Peloponnesian War?"
One can not overstate the transcripts' value to historians, archaeologists, anthropologists, sociologists, and even political scientists. Already, many are being forced to make grand reinterpretations of life and society in the ancient world and even our own; the previously unknown participation of an Athenian "Amazon" phalanx in the final stages of the war has already had reverberations in the present-day debate over women in the military. While the basic facts and events remain the same, ancient history, as we thought we understood it, has been turned on its head. Where once was consensus, now stands the same sort of diversity and interpretative debate with which all in the academic profession have become familiar. Thus, I present the transcripts in as whole a manner as possible, with none of the biased editing for style, legacy, and such that often characterizes such works. Fortunately, the HPSA conferences were professional, collegial affairs, so there was no need to censor for expletives or good taste, as one often has to do with more contemporary tapes.

Reading their words, one actually joins the ancients as they deal with the major political issues of their time. For the first time, modern scholars can hear their forefathers at their best as they debate the validity of their views. The contemporary reader is likely to find that no one scholar is proven wholly "correct" or emerges triumphant at the expense of the others. Just as today, this was a group of intelligent sages (essentially political scientists without the science), who were attempting to make sense of a complex world. Disagreement was not only allowable, it was rewarded. Rather than providing the unchallengable proof of any one theory's correctness, the transcripts reveal that, at least to its contemporaries, ancient history was a collection of case studies open to dispute. It is ironic that at the end of the second millennium, the field is still focused on the search for that comprehensive, but elusive, single truth.

Regardless, the reader should take away from this transcript an appreciation of the ancients' wisdom. One gains a clarified insight into the state of the field and the relationships between the differing theories, best demonstrated by the way the logics of competing theories feed off of one another. The scholars of the HPSA truly emerge from the following pages to join the academic pantheon. In Thucydides's own words, the ideas captured in these transcripts do become "a possession for all time." 
Note: This section of the transcripts is from the 42nd HPSA conference held in 429 BCE (by our reckoning). The Peloponnesian War is in its second year, with the split in the HPSA ranks mirroring the political division of Greece between the Delian League led by Athens and the Peloponnesian League of Sparta. It was an extraordinary period in the history of the academic organization. Limiting the potential diversity of views, only Athenian members were given chairs of honor. Nevertheless, the discussion was intense. This partial transcript (the third find in the Halki dig) begins right after Thucydides, a promising young scholar, presented the first chapter of an apparent work in progress, in which he outlined his thoughts on the origins of the current war.

Waltzes: I must concur with young Thucydides about the origins of this conflict. In fact, I believe that it will become a near classic case revealing the true cause of war. The pointed analysis that "the growth of the power of Athens, and the alarm which this inspired made war inevitable," shows his appreciation for how the makeup of the system itself dictated conflict. Theory should forget about the individual attributes of each state or even of the citizens within. This highest level structure and its distribution of power is what drives relations between states. Interaction is positional. One doesn't even have to identify which specific states one is talking about to reach the same conclusions.

Our city-states exist in a self-help system. Except perhaps the gods, there is no higher authority to whom they must answer, so the use of force is a constant possibility. Position maintenance and survival are the concerns driving each state's behavior. As our leader Pericles correctly warned us, we must learn to depend solely upon ourselves. Power distributions - as defined by capability, not end results-are what matter; each power views the world through a comparative lens, measuring other states' gains relative to its own. In the years leading up to the war, there was a growth in Athenian power. As much as we hated the Spartans, their balancing response was natural and to be expected. With the decline of a unifying exterior threat from Persia, the Spartans understandably feared for their survival in what was, in effect, a closed system.

It's really quite simple. A general understanding of the structure gives rise to general predictions. Thucydides is quite correct in his reductionist approach of focusing on the systemic features that affected behavior and drove the conflict, not the events that sparked it. What wonderful parsimony and elegance of explanation this achieves!

Jervises: But Waltzes, there still are some flaws within the structural explanation, as illustrated by our young scholar's premature case study. Specifically, the distribution of power created a bipolar arrangement, with two opposing alliances dominated by Sparta and Athens. But the structural model points to just such a situation, with only two great powers, as being optimal for maintaining peace and stability.
Each power was strong enough to depend on just itself and was less likely to misjudge its own or the other side's strengths. Plus, the rigidity of alignment allows the two a flexible strategy and weathering of defections. Considering the power distributions inside of Greece, it would be a hard case to claim that there was a multipolar situation, the sort claimed to be most unstable. It is laughable to consider such states as Macedonia as being on any sort of equal level with Sparta and Athens. In the form of the Delian and Peloponnesian Leagues, these two great powers control the only true alliance structures that matter. None of the middle powers have even half the might of Athens and Sparta.

Furthermore, if it was the growth of Athenian power that caused natural balancing, how do we explain the actions of our allies, who, by Waltzes' account, should have sought to balance our growth in power by joining the Spartans and been rewarded handsomely by our enemies for their defection. Instead, you'll remember, they followed the likely winners-we Athenians, of coursemuch in the way a crowd gathers around a parade; you know, what some call "bandwagoning." If Waltzes is right, it is fortunate that both Spartans and our own allies forgot these important-sounding laws of balancing. Perhaps the goddess of wisdom chose to bless only her namesake.

The central question we must ask is, given the fact that there were two sides seemingly matched in power, what forces prompted them to perceive each other as so dangerous that they chose to enter a battle to the death, instead of staying in a supposedly stable bipolar arrangement?

Schwelleres: First off, I think I can answer on behalf of Waltzes by reminding us of the difference between system stability and actual peace. But, there is another way to take the systemic approach that answers this question; one that still focuses on power and state-centrism, but reaches slightly different conclusions. In defining all states as simple security seekers interested only in maintaining their relative positions, Waltzes suffers from a status-quo bias. I proffer that some states are dissatisfied with where they lie in the alignments and, thus, take risks that this relative-gains approach cannot explain. The key threat to the system is not just a number of clown-like bumblers, prone to misjudging the state of affairs, but the existence of certain states, hungry and aggressive like wolves, who challenge the status quo in an attempt to gain power. This is at the crux of the war. Let's admit it, our Athens was in search of power and we took risks to obtain it. There is no shame in this; it is the natural order of things.

Morgenthaues: Schwelleres is on to something here. States define their interests in terms of power and are not limited in their means to gain it. Young Thucydides, take note: It's a fact of life that the strong do what they can and the weak suffer what they must.... Go ahead and quote me on that.

Athens was growing in power before the war, and, I 
must add, not just in military capability as measured by numbers of troops and ships. As Pericles reminded us at the first funeral oration, economic strength also easily translates into power, such that the Spartans anticipated our coming dominance and tried to preempt it. This is similar to Waltzes' telling, but with subtle, classical differences that I think are more in line with what Thucydides really intends. Don't forget the justifications of the war presented to the Assembly just last year. Fear for survival of our state was never the reasoning behind pushing for war. Rather, it was that the Spartans were denying us our deserved leadership of all the Hellenes.

Wolferes: This is where I question this approach. I simply cannot accept the idea that some type of ethical standard doesn't bind states. Didn't anyone take the classical ethics seminar over at the Academy? Survival may be the highest value, but not all issues are ones of state life or death, including the ones leading up to this conflict. Our expansion and actions towards the lesser Ionian citystates [the Greek island states that Athens had turned into virtual colonies] should have been tempered with a realization of their greater negative impact. There is an inherent contradiction in leaders claiming moral principles to guide the individual and then pursuing immoral means and goals for our state. Like the people that make them up, states should also be bound by morals, merely under more difficult circumstances. Just because those of us who are realistic believe in power, does not mean that we all can't just get along.

[Assorted hisses and boos from the crowd dominate the transcript at this point]

Unidentified: How can you even suggest the Spartans are moral actors? This is treason and heresy! Who let this guy in?

Gilpines: I don't think that the more realistic of us are suggesting that ethics are useless. It's simply that an examination of war can proceed better without resorting to questions of morality.

Vasquezes: But hold on a minute. Are there not connections between this negative type of "realist" reasoning and their implementation in war?

Wendtes: This is exactly what I have been trying to tell you all! This structure you speak of is like one of Democritus's tiny unseeable "atoms." We can't see or touch it. It is not of any material like gold or marble, but a construction of our own minds. Thus, there remains a possibility of transforming how we see ourselves. If we returned to thinking of all of us as noble Greeks and Hellenes, first and foremost, none of this "rationalized" madness would be occurring and we could transform the system to one of cooperative security rather than destructive anarchy.

Goldsteines: Quite so. In Thucydides' work, one can see that ideas themselves have had power and impact. The concept of how to treat an opposing state, or even a former colony, has tangible impacts on how states interrelate.

Gilpines: That's enough of this fluffy babble about "ideas" and "identity." Let's remember that this is the HPSA and any further unconventional, immaterial outbursts will be dealt with!

To continue with my earlier point, the systemic approach has its merits, but I think we miss the grand picture of what the scope of this war truly signifies. It has been like the Charybdis, sucking in all the other states in Greece. This is not a battle between Athens and Sparta, from which the other states have stood aside. This is a war to determine who will be the leader of all Hellas, a concept which, unfortunately, my colleague Waltzes doesn't allow.

In fact, this war was presaged by the diplomatic conflict between Athens and Sparta over who would be at the head of the Hellenic Confederacy, the old alliance against the Persian invaders. Greece is a rational system of unitary actors, but it also is a system with an oligopolistic control structure. A type of order does exist; one determined by the strength and prestige of the dominant state, which I call the "hegemon." This hegemon provides the other states protection and other services in exchange for its position. And, yes, my young friends, it even exports values and ideologies to help it maintain control. The hegemon is both judge and executioner; it makes the rules and enforces them.

However, only one state can be the hegemon. War tends to be the method of change in this system. Because of the uncertainty of power, only a conflict can determine whether a disjuncture exists between power and prestige. Challenger states, such as Schwelleres spoke of, seek change when they think that the relative costs of changing the status quo are less than the benefits of possibly capturing total hegemony. However, one critical risk that both Pericles and Thucydides, to their credit, are aware of is that, besides having its position taken away by a rival, a hegemon can just as easily waste away due to over-expansion. All this recent talk of interventions into Egypt and even Syracuse should give us great alarm.

Snyderes: If I may interrupt. . . . Think of Assyria, the Hittite kingdom, and most recently Persia under those fools Darius and Xerxes. There seems to be a clear proclivity of great powers to aggressively overextend and then waste away. Great states seem to believe their own myths, especially those that teach that expansion brings security. It's as if the wind "blows back" their own boasts of strength.

Gilpines: Yes, but the difficulty is that all sorts of great powers-empires, autocracies, oligarchies, and maybe even our own democracy-tend to have this problem. Another facet to be aware of is the danger that the trial of strength of a hegemonic war could even leave both sides so exhausted that neither will be able to assume 
the mantle of leadership. If that happens here, then the question is not "Athens or Sparta?" but who will emerge to become the new hegemon? By the gods, I hope it isn't those horrible Persians again! Even some barbarian Italian state would be preferable.

Doyles: Gilpines does well to consider who will lead if the current war does nothing but weaken all the combatants. But, like the previous accounts, his too easily discounts the domestic factors that impact on the function of this system. While this method of not distinguishing between state alpha and state beta may sometimes yield general predictions, it also misses out on some of the truly intriguing phenomena of both this war and the history of democracy in general.

Unidentified: What do you mean "history of democracy?" I've got sandals in my closet older than most of these supposed "democracies!"

Doyles: Yes, I see. But, while the data is limited, it is not pure chance that our allies tend to be democratic and all those in the Peloponnesian League are oligarchies. This implies that the form of domestic government goes some part of the way towards explaining and predicting who will go to war, and maybe even why. Perhaps even the reason for the current "bandwagoning" is that the Ionian states find us more trustworthy as fellow citizens, due to the open deliberation of our decision process. Remember that the Spartans despise and fear our domestic model of popular rule. Remember, also, that the overthrow of the last oligarchic elements in our government [in $462 \mathrm{BCE}$ ] was coincident with the final breakup of the joint Hellenic League into the two alliances. I do not wish to imply that we are somehow less warlike because of our democracy, but that this may be behind the makeup of the two alliances. Perhaps, the characteristics of democracy, such as communal responsibility and norms of compromise, make it harder for democracies to fight other democracies.

There is also a greater allowance for factors below interstate structure in Thucydides's text than we have thus far discussed-though, I am sure that in this sophisticated day and age few of us would agree with his racial stereotypes of the Dorians versus the Ionians, who make up the two alliances. However, his focus on the particular force of "Athenian spirit" leads me to agree that, while Sparta may be characterized as isolationist and interested solely in maintaining a closed system, Athens, as typified by its transnational extension and number of colonies, is something different. Our Athens is not just any state, but an outward-looking empire.

The public-political institutions of Athens have led to a restless, commercial character of its citizens. This impacts on our external relations much differently than the oligarchic society does on Spartan foreign policy. A mutual desire for profit also helps to check conflict with other merchant states. Compared to the Spartans or the Persians, Athenian civilization leads to prosperity and others seek to join us in our success. ... Yes, Hunting- tones, I see your hand, but you'll have to wait your turn on the point on civilizations.

This expansion to empire is what gives us our strength. Our metropole is dependent on it. As Thucydides wrote, whereas Sparta must rule by force with the support of the oligarchs, the people of other states themselves consistently choose to ally with Athens. The real danger of this war is that the domestic unity that distinguishes us from lesser states will be tried severely.

Gourevitches: This last point of Doyles indicates that the currents of politics run in both directions. While internal factors affect external relations, external interstate processes also impact on domestic institutions. It is evident that our close economic ties with and military intervention in the Ionian states has certainly affected their choice of democratic institutions. Let's be frank, their adoption of Athenian-style constitutions was no coincidence. Closer to home, the elites within Athens equally draw their power from sources outside our borders and make policy in full awareness of their own personal interests. Thus, all the previous unitary theories we have heard are weakened. Like it or not, interdependence has long been a factor in state relations.

Keohanes: Did I hear someone mention interdependence? That's exactly what I wanted to bring up. You see, Classical Age states just aren't self-sufficient like they used to be back in the Bronze Age. If you require empirical evidence, just take a look in your kitchen amphorae. I'll wager they are filled with grain from Thrace, or olives grown on Rhodos. States are beginning to have a greater sensitivity and vulnerability to all levels of actions by other states. One can definitely see such a phenomenon within the Delian Confederation, and I think the existence of such an institution may be part of it. Led by self-interest, states enter into regimes because they facilitate the development of norms, information flow, and institutionalized expectations, all of which make cooperation easier.

Waltzes: But why, then, didn't the Hellenic League have such a cooperative influence on relations between Athens and Sparta? In the end, power considerations proved to be the true determining factor. These institutions are just intervening variables, which get in the way of elegant theory. The problem with all the contradictory explanations I keep hearing is that besides being inductive, by necessity, they are forced to rely on innumerable variables simply because they underestimate the strength of anarchy. Why tack on some theoretic decoration that deviates from the system level? It's like what I tell my students back at the Waltzian school, "Keep it simple. Stick to power and it all works out."

Jervises: Let's go back to the question I was asking earlier as to why two states would enter into a battle to the death when doing so may not be in either's interest? While the previous theories explain much, few have credited the power simple misperception has to drive 
conflict. It is almost as if Athens and Sparta face one of the Sphinx's riddles where, in order to feel secure, each must continually prepare for war. But in the end, this makes each state more insecure as the other states do the same. Now, at this time of stalemate in the war, we see that forces on the defensive have the advantage, so that such military buildups were in the end unnecessary. But who knew that this would be the case before the fighting actually began?

Even worse, there was no way to distinguish efforts to defend oneself from preparations to attack the other. Take the case of our own Long Walls [Athens's outlet to the sea, Pireaus harbor, was protected by high fortifications built before the war despite the protests of the Spartans]. What could be less threatening than a wall; I mean, the bricks certainly can't get up and attack anyone. But the construction of the walls confirmed the Spartan's suspicions that Athens was to be Sparta's enemy and polarized the two sides. After the Persian invasion, we could not feel safe without having walls around our city. But the Spartans could not feel safe with them, since the walls freed up troops normally kept in reserve for defense of the city for offensive use elsewhere.

Bueno de Mesquites: But that implies that this war is a mistake. Is it not possible that war is not a mistake, but a deliberate, rational choice? The alliance patterns must be related somehow, as it appears that the patterns of alliance are linked to shared interests. If we assume that both states are rational actors and both sides chose to fight in the end, this means that they must have derived some sort of positive utility from their respective choices.

Fearones: But is that really all that interesting by itself? It doesn't tell us the "when" or the "why," or even the "how" of the calculation of these utilities. That someone had to benefit was fairly clear already. What next? Predicting that Athens is unlikely to attack some random village on the Tiber River, just because some abacus calculation says distance matters.

I agree, Sparta and Athens chose to go to war; but it is more important, and interesting, that both, seemingly irrationally, thought they would definitely win. Obviously, this is not possible. But it still makes logical sense, as even rational states can take risks and choose war. Thucydides did all a favor in recording the speeches made in both capitols before the war. Both Athens and Sparta felt certain that they would win! This was because neither side had full knowledge of the other's strength and willingness to fight. The problem is that even if we had chosen to share this information, would anyone here have believed the Spartans? No. Each side had a true incentive to hold private information, misrepresent, and even lie. Importantly, this was much easier for the undemocratic Spartans. Their closed society of oligarchs and helot slaves meant that was no cost to their public signals.

Coxes: But perhaps we should pull back for a minute here. Each one of us seems to be searching to create a single universalistic explanation that applies not just to this war, but to politics in general. There may be other accounts linked to specific eras or stages of history of which we have not spoken.

Gradutes [Some obscure, young scholar presumably lost to the ages]: Despite our good fortune to live at the center of the world, this place may very well be more complex than we even realize. It is important that we remember that our theories are all just models of reality as we understand it at this time. There is something to be said for integrating like theories, but in our field there often seems a dangerous struggle for theoretic supremacy to the denigration and exclusion of others. This can result in value bias and a focus on the static. While it may lead us to pretty and elegant theories, parsimony may not be a good thing in and of itself.

However, the fact that so many diverse explanations seem applicable in some way to the exact same case should signify that all of us are on to something. Perhaps each of these theories can be visualized as tools, of a sort, for understanding, explaining, and predicting. Some are quite specialized like those pointy little tooth cleaning sticks they have up at the counter, while others may be more general, like a knife or a saw. Sometimes they can perform similar tasks, but, obviously, each is more useful in some situations and less useful in others. Maybe even one day, some inventive little army will find a way to put them all together. But my point is, once you have determined a tool's strengths and usefulness, you don't just throw out all the others. Rather, you save them as part of a complementary tool-set, ready for potential use.

The reward of openness to ideas outside one's outlook is that each theory, once its logic is proven valid, can capture different aspects and offer different insights. Call me a naïve young idealist, but isn't our driving goal as scholars not to triumph in the market of ideas, but simply to understand?

Most likely, this debate of theories won't be resolved this morning. So, before we break, I think we should all commend our author for an effort well attempted. Despite our disagreements over the theoretic implications of this war, from the exact same account, each of us has found at least partial evidence of our own certain truths. But we have heard little from the man of the hour himself. Thucydides, what's been your reaction to this discussion?

Thucydides: If it be judged useful by those inquirers who desire an exact knowledge of the past as an aid to the interpretation of the future, which in the course of human things must resemble if it does not reflect it, I shall be content. In fine, I have written my work, not as an essay which is to win applause of the moment, but as a possession for all time.

That had a certain elegance to it. Maybe, I should put that into the Intro. Scribe, did you get that?

\section{[End transcript]}




\section{References}

Bueno de Mesquita, Bruce, and David Lalman. 1986. "Reason and War." American Political Science Review 80(December): 1113-29.

Doyle, Michael. 1983. "Kant, Liberal Legacies, and Foreign Affairs, Part I." Philosophy and Public Affairs 12(Summer): 20535 .

—. 1986. Empires. New York: Cornell University Press.

Fearon, James. 1995. "Rationalist Explanations for War." International Organization 40(Summer): 379-414.

Gilpin, Robert. 1981. War and Change in World Politics. New York: Cambridge University Press.

Goldstein, Judith, and Robert Keohane. 1993. "Ideas and Foreign Policy: An Analytical Framework." In Ideas and Foreign Policy:
Beliefs, Institutions, and Political Change. New York: Cornell University Press.

Gourevich, Peter Alexis. 1978. "The Second Image Reversed." International Organization 32(Autumn): 881-912.

Jervis, Robert. 1976. Perception and Misperception in International Politics. Princeton: Princeton University.

-. 1978. "Cooperation under the Security Dilemma." World Politics 30(January): 167 214.

Keohane, Robert. 1986. Nonrealism and Its Critics. New York: Columbia University.

- and Joseph Nye. 1989. Power and Interdependence: World Politics in Transition. 2nd ed. New York: Little Brown.

Morgenthau, Hans. 1954. Politics among $\mathrm{Na}$ tions. 2nd ed. New York: Knopf.

Schweller, Randall L. 1996. "Neorealism's Status Quo Bias: What Security Dilemma?" Security Studies 5(Spring): 225-58.
Snyder, Jack. 1991. Myths of Empire. New York: Cornell University Press.

Thucydides. 1993. The Peloponnesian War. Trans. Richard Crawley. New York: Random House.

Vasquez, John. 1993. The War Puzzle. New York: Cambridge University Press.

Waltz, Kenneth. 1959. Man, the State, and War. New York: Columbia University Press.

- 1979. Theory of International Politics. Reading, MA: Addison-Wesley.

Wendt, Alexander. 1992. “Anarchy Is What States Make of It: The Social Construction of State Politics." International Organization 46(Spring): 391-425.

Wolfers, Arnold. 1962. Discord and Collaboration. Baltimore: Johns Hopkins University Press.

\section{Attention Members!}

Now is the time to submit your data for the Centennial Biographical Directory

For the first time in over a decade, APSA will publish a Biographical Directory of Members. This directory will include, among other new features: members' publications and professional honors; current/previous professional and administrative positions; personal URLs; and essays on the professional and scholarly contributions of political science in honor of the Association's Centennial. The Directory will be published in Winter 2000-2001.

Please visit the Electronic Data Collection Site at http://search.apsanet.org to enter or update your biographical data. All data for the Directory must be entered electronically. Please follow these instructions.

Type in your username which is your last name as it appears on APSA mailings Type in your password which you will find as your member number on journal labels, membership cards, and invoices recently mailed to you from APSA.

The computer will guide you through the remainder of the process. Only current members will be included in this important professional publication. Renew or join today by filling out the online form available at http://www.apsanet.org.

You may also renew your membership at the Electronic Data Collection Site. If your login cannot be completed, simply click the highlighted phrase, membership recently expired?, and renew your membership online.

To ensure that your biographical information will be accurately published, please visit http://search.apsanet.org to submit data. 
Robert B. Anderson, Ben and Janice Wade Outstanding Teaching Award, Bridgewater College, Fred Baumann, Trustee Award for Distinguished Teaching, Kenyon College, Dr. Thomas J. Bickford, Outstanding Teaching Award, University of WisconsinOshkosh, Bruce Bimber, 1998-99 UCSB Foundation Academic Senate, University of California-Santa Barbara, Julian Bond, University- Wide Award for Adjunct Faculty, American University, Steven Brown, Cardinal Key Best Professor, Auburn University, Leann Brown, Teaching Improvement Award, University of Florida, Frank Bryan, Kroepsch-Maurice Excellence in Teaching Award, University of Vermont, Julie Bunck, Exemplary Multicultural Teaching Award, University of Louisville. Kenneth Campbell, Excellence-in-Teaching Awards, University of Delaware, Robert Clark, University Award for Excellence in Teaching, George Mason University, Dewey Clayton, Exemplary Multicultural Teaching Award, University of Louisville, Brian Crisp, Overall Most Outstanding Teacher, University of Arizona, Gregory Domin, Honors Professor of the Year, Northern Arizona University, Christopher M. Duncan, Alumni Association Upper-Level Teaching Award, Mississippi State University, John W. Epperson, Distinguished Teaching Award, Simpson College, Stephen J. Farnsworth, Mary W. Pinschmidt Award \& Richard Palmieri Outstanding Professor Award, Mary Washington College, Daniel Franklin, Distinguished Honors Professor, Georgia State University, Anthony Gill, Distinguished Teaching Award, University of Washington, Kerstin Hamann, Teaching Incentive Program Award and College of Arts and Sciences Excellence in Undergraduate Teaching, University of Central Florida. Michael Harris, Teaching Excellence Award, Eastern Michigan University, David Hedge, College of Liberal Arts and Sciences Teaching Award, University of Florida, Pamela Imperato, McDermott Award for Departmental Excellence in Teaching, University of North Dakota, Aubrey Jewett, Teaching Incentive Program Award, University of Central Florida, Renee Johnson, Teaching Improvement Award, Univer- sity of Florida, Timothy Kaufman-Osburn, Robert Y. guished Teaching in Outstanding Junior University, Claire 1999-2000 UCl Acatinguished Assistant, nia, Irvine, Mary Grisez Award for Departmental ing, University of North Kweit, McDermott Award cellence in Teaching, Unikota. Nancy Lind, OutAward, Illinois State UniverState Board of Regents lence, University of NorthLopez, Excellence in the Council for Excellence ing, University of Illinois, nois-Chicago, Tukumbi Kasongo, The Excellence Wells College, Thomas more Class Faculty ExcelNorthwood University, SUNY Chancellor's in Teaching, SUNY ColStephen Markovich, for Departmental ExcelUniversity of North Dakota,

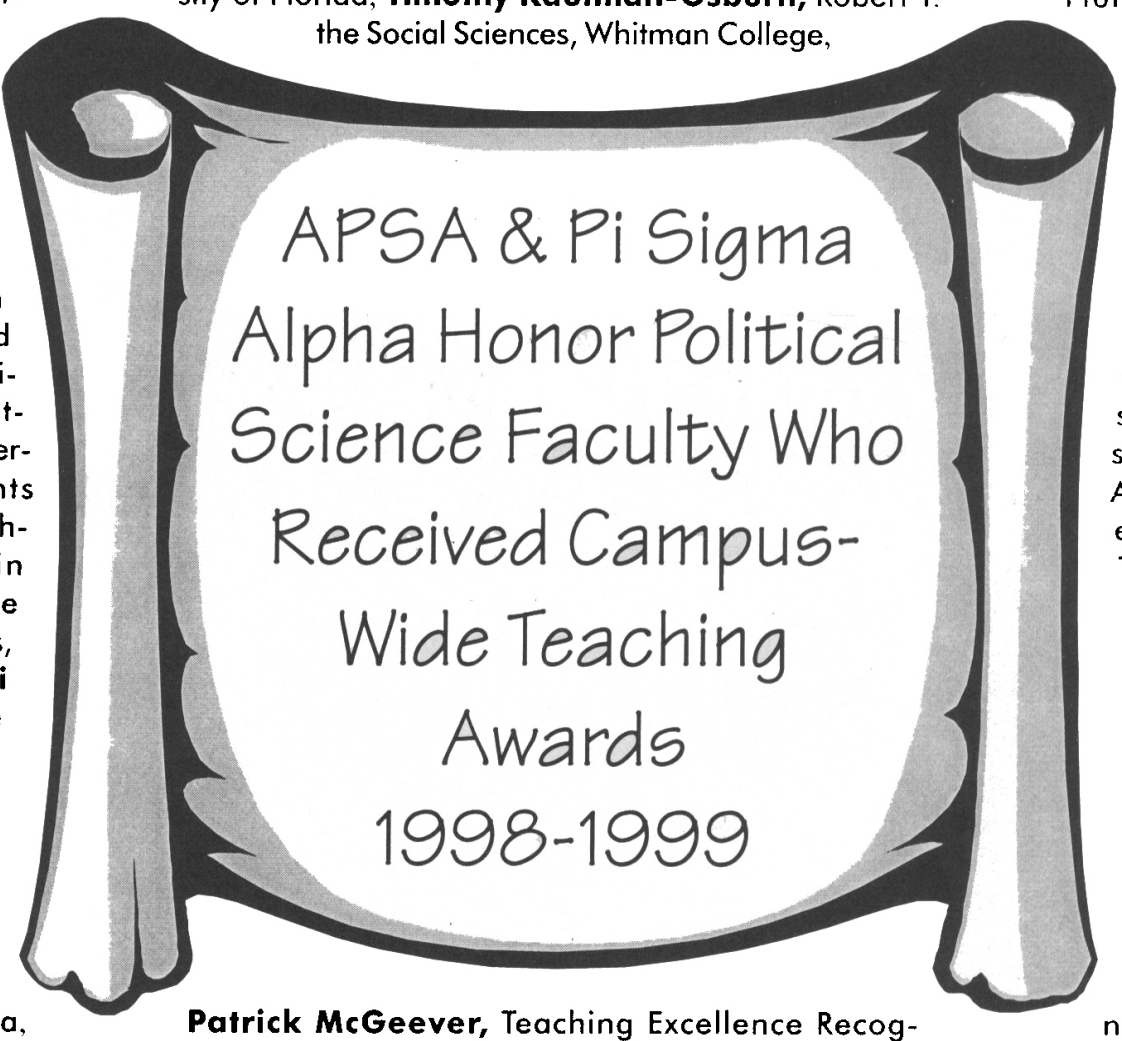
Fluno Award for DistinKaren Kedrowski, Professor, Winthrop Jean Kim, demic Senate, "DisUniversity of CaliforKweit, McDermott Excellence in Teach:Dakota, Robert for Departmental Exversity of North Dastanding Teacher sity, Thomas Lindsay, Award for Faculty Excel. ern lowa, Juan J. Teaching Award from in Teaching and LearnChicago., Univ of !lli$\mathbf{L} \mathbf{u} \mathbf{m} \mathbf{m} \mathbf{b} \mathbf{a}$ in Teaching Medal, Luptowski, Sopholence Award, Michael E. Lynch, Award for Excellence lege at Oneonta, McDermott Award lence in Teaching, nition Award, Indiana University-Purdue University at Indianapolis, Chris McMahon, College of Liberal Arts Teaching Award, University of Minnesota, Duluth, J. P. Monroe, 1999 Excellence in Teaching Award, University of Miami, James Morone, Barrett Hazeltine Teaching Award, Brown University, Louis Ortmayer, Hunter Hamilton Love of Teaching Award, Davidson College, L. Marvin Overby, Cora Lee Graham Award for Outstanding Teaching of Freshmen Students, University of Mississippi, Suzanne Parker, University Teaching Award, Florida State University, Theodore Pedeliski, McDermott Award for Departmental Excellence in Teaching, University of North Dakota, Mark J. Peterson, Outstanding Faculty Award, Pittsburg State University, G. Bingham Powell, University Award for Excellence in Graduate Teaching, University of Rochester, Ronald Pynn, McDermott Award for Departmental Excellence in Teaching, University of North Dakota, David Ray, Regents' Award for Superior Teaching, University of Oklahoma, Lloyd I. Rudolph, Faculty Awards for Excellence in Graduate Teaching, University of Chicago, Richard Scher, Teaching Improvement Award, University of Florida, David Schlosberg, Outstanding Teaching Scholar, Northern Arizona University, Joel Joseph Schwartz, University Professor of Distinguished Teaching, University of North Carolina-Chapel Hill, Nathan Schwartz, Exemplary Multicultural Teaching Award, University of Louisville, Timothy Sherratt, Senior Distinguished Faculty Award, Gordon College, Anthony D. Simones, University Foundation Award for Teaching and Governor's Award for Teaching, Southwest Missouri State University, David J. Sousa, Dean's Teaching Award, University of Puget Sound Politics and Government, Mary E. Stuckey, Elsie M. Hood Outstanding Teacher Award, University of Mississippi, Regina Tifunik, Frances Davis Award for Excellence in Undergraduate Teaching, University of Hawaii at Hilo, Ken Wald, College of Liberal Arts and Sciences Teaching Award, University of Florida, Donna Pritchard Wasserman, UM-D Outstanding Teacher Award, University of Michigan-Dearborn, Claude Welch, The Milton Plesur Award, SUNY-Buffalo 